\title{
Carriage of extended-spectrum beta-lactamase-producing Enterobacteriaceae by healthy school children from two remote villages in western Cameroon
}

\author{
William Lelorel Nankam NGUEKAP ${ }^{1}$, Thérèse Ingrid LONTSI ${ }^{1}$, \\ Anicette Chafa BETBEUI ${ }^{2}$ and Simon Ngamli FEWOU ${ }^{*}$ \\ ${ }^{I}$ Department of Clinical Biochemistry, Faculty of Medicine and Biomedical Sciences, \\ Université des Montagnes, Bangangté, Cameroon. \\ ${ }^{2}$ Laboratory of Bacteriology, Yaoundé University Health Center, Yaoundé, Cameroon. \\ *Corresponding author; E-mail: simon.fewou@gmail.com
}

\begin{abstract}
Received: $11-07-2020$
Accepted: 18-12-2020

Published: $31-12-2020$

ABSTRACT

Carriage of extended-spectrum beta-lactamases (ESBL)-producing Enterobacteriaceae by healthy children can increase the risk of developing a lethal pathological infection. The objective of this study was to determine the rate of ESBL-producing Enterobacteriaceae carriage among children in remote villages in western Cameroon. We collected fresh stool samples from 110 healthy primary school children between 2 to 5 years old in two remote villages. The bacteria isolates were characterized using the Api $20 \mathrm{E}$ gallery, disc diffusion, and double-disc synergy test. Logistic regression analysis was used to determine the risk factors associated with the carriage of ESBL-producing Enterobacteriaceae. Data analysis indicated that a total of 24 children in 110 (22\%) investigated were positive to ESBL-producing Enterobacteriaceae. Moreover, 24 (67\%) out of 36 bacteria isolates were ESBL producers and 15 (61\%) out of 24 being Escherichia coli. Other ESBLproducing bacteria were Klebsiella pneumoniae (3\%) and Kluyvera spp (3\%). We also isolated a small proportion of bacteria showing resistance to high-level cephalosporins, which overall represented $33 \%$ of the total bacteria isolates. Furthermore, risk factors associated with the carriage of ESBL-producing Enterobacteriaceae were the use of pesticides in agriculture and farming practice. The current result suggests that frequent contact to antibiotics is not the only reason for the development of resistance and confirm that resistance can be induced by chemicals from pesticide origin.
\end{abstract}

(c) 2020 International Formulae Group. All rights reserved.

Keywords: Carriage, Enterobacteriaceae, ESBL, Escherichia coli, Healthy children, Remote villages, Western Cameroon.

\section{INTRODUCTION}

The resistance of Gram-negative bacilli to antibiotics is considered a global challenge for healthcare due to limited treatment options and is also associated with high mortality (Schwaber and Carmeli, 2007; Boucher et al., 2009; WHO, 2014). The production of extended-spectrum B-lactamases (ESBL) is the mechanism by which the
Enterobacteriaceae species induce antibiotic resistance (Munita and Arias, 2015). Whereas the infection with multidrug-resistant organisms has been initially associated with the hospital environment, there is now increasing evidence of high rates of carriage of ESBL-producing microorganisms identified in community settings (Woerther et al., 2013; Ny et al., 2017). It is therefore evident that the 
communities are becoming important reservoirs for antibiotic-resistant bacteria. Recent investigations suggest that Escherichia coli strains producing the ESBL enzyme are the Enterobacteriaceae responsible for community infections (Rodríguez-Baño et al., 2004; 2010; Arpin et al., 2009) and its prevalence is increasing in resource-limited countries where infectious diseases, poverty, and malnutrition are endemic (Bebell and Muiruc, 2008).

Whether the infection is acquired in a hospital or community, the digestive tract is the main reservoir from which enterobacteria originate (Donskey, 2004; Carlet, 2012). Moreover, it is the site where resistance genes are exchanged between bacteria species and antibiotic exposure causing the overgrowth of resistant bacteria (Duval-Iflah et al., 1980; Woerther et al., 2014). Intestinal carriage of pathogenic bacteria is common in resourcelimited countries due to poverty and poor hygiene conditions (Bryce et al., 2016). Therefore, persons colonized are at risk of subsequent infection (Mesa et al., 2006; BenAmi et al., 2006; Woerther et al., 2013) and this has an impact on the prevalence of ESBLproducing Enterobacteriaceae among adults in rural areas in Africa where hygiene is almost inexistent (Farra et al., 2016). Moreover, high prevalence of fecal carriage of ESBLproducing Enterobacteriaceae has also been observed among children living in rural Africa characterized by a high level of poverty and poor hygienic conditions (Woerther et al., 2011; Farra et al., 2016; Tellevik et al., 2016) with as consequence the high mortality rate among children.

From the above observations, we conducted this study to determine the prevalence of carriage of ESBL-producing Enterobacteriaceae among school children from two remote villages in the west region of Cameroon. Indeed, in those villages, the absence of basic healthcare exposures was queried and no antibiotic treatments during the last three (3) months were the main selection criteria. Recovered Enterobacteriaceae isolates were tested for susceptibility to relevant antibiotic classes. Data analysis indicated $22 \%$ carriage of EBSL-producing Enterobacteriaceae of investigated children. Moreover, risk factors such as the use of pesticides in agriculture and farming practice were also reported. The data gathered in this study is of paramount importance since it may contribute to design strategies to curtail the emergence and spread of ESBL-producing Enterobacteriaceae among children in rural Africa and devise innovative therapeutic approaches against multidrug-resistant organisms.

\section{MATERIALS AND METHODS Study setting and population}

This prospective study was performed between October 2017 and July 2018 in two primary schools (Moineaux de Bafou Ballefer and oiselets de Nzi) of the Bafou village near Dschang, the largest city of the Menoua subdivision and in one primary school (École publique projet route du Noun 2) of a remote village (route du Noun) near Bangangté, the largest city of the Ndé subdivision. Healthy children between 2 to 5 years old were included $(\mathrm{n}=110)$. A standardized questionnaire was performed and submitted to the parents who have provided answer on behalf of children for collection of demographic information on children (gender, antibiotic treatment during the last 3 months and never been hospitalized) and parents (Parents' education level, Breeding by parents, Use of antibiotics in breeding, farming practice by parents, and the Use of pesticides in agriculture).

\section{Sample collection and bacterial isolation}

A freshly emitted stool specimen from each child and contained in the coproculture pots were stored in the icebox and send to the laboratory of microbiology at the "Clinique Universitaire des Montagnes (CUMs)" for analyses. Fecal specimen from each child was collected and cultured on MacConkey agar within six hours as follow. $0.5 \mathrm{~g}$ of fecal sample was suspended in $5 \mathrm{~mL}$ of sterile $0.9 \%$ saline. Each suspension was seeded on McConkey agar supplemented with céfotaxime at $1 \mathrm{mg} / \mathrm{L}$ to select the Enterobacteriaceae resistant to the thirdgeneration cephalosporins (3GC). After seeding, the plates were incubated for $48 \mathrm{~h}$ at $37{ }^{\circ} \mathrm{C}$. One colony representing each distinct 
colonial morphotype was isolated from supplemented MacConkey agar and further analyzed by gram coloration and oxidase test. Bacilli gram-negative and negative in oxidase test were seeded on nutrient agar and incubated for 24 hours at $37{ }^{\circ} \mathrm{C}$. After 24 hours, the colonies suspended in $0.9 \%$ saline to yield a turbidity equivalent to that of the 0.5 McFarland standards appropriate were prepared for the biochemical identification and the antibiotic susceptibility testing.

\section{Biochemical identification \\ Enterobacteriaceae}

of

The Biochemical identification was carried out according to the recommendations of the manufacturer of gallery Api $20 \mathrm{E}$ (Biomérieux, Marcy l'Etoile, France), which constitutes a standardized system of identification of Enterobacteriaceae.

\section{Antimicrobial susceptibility testing}

Susceptibility tests were carried out by the Kirby-Bauer disk diffusion susceptibility test using 15 conventional antibacterial drugs that are commonly used in Cameroon as described (Piebeng et al., 2014; Toudj et al., 2017). We prepared a 24 hours bacterial pure culture obtained by streaking bacterial isolates on fresh nutrient agar and allowing for overnight aerobic incubation at $37{ }^{\circ} \mathrm{C}$. From the resulting bacterial population, a suspension to the density of a McFarland 0.5 turbidity standard prepared in $0.9 \%$ saline was adjusted to the final opacity recommended for susceptibility tests by agar diffusion technique on Mueller Hinton agar. Test procedures and interpretations were done according to the standard guidelines recommended by the "Comité de l'Antibiogramme de la Société Française de Microbiologie (CA-SFM, 2015). We used $30 \mu \mathrm{g}$ of each antibiotic disc that included amoxicillin, cefoxitin, cefotaxime, ceftazidime, nalidixic acid. Besides, discs of $10 \mu \mathrm{g}$ were used for ertapenem while discs of $5 \mu \mathrm{g}$ were used for gentamicin, kanamycin, amikacin, ciprofloxacin and ofloxacin. A fosfomycin disc was used at $50 \mu \mathrm{g}$. The combination of trimethoprimsulfamethoxazole and amoxicillin/clavulanic acid was used at 23.75/1.25 $\mu \mathrm{g}$ and 20/10 $\mu \mathrm{g}$, respectively. Escherichia coli (25922) from
American Type Culture Collection (Manassas, Virginia, USA) were used as a reference for quality control.

\section{Phenotypic screening for ESBL-producing Enterobacteriaceae}

The detection of ESBL(s) production in Enterobacteriaceae was performed using a double-disc synergy testing as described (Brown and Alhassan, 2014; Iqbal et al., 2017, Ngassam et al., 2017). Briefly, amoxicillinclavulanic acid $(20 / 10 \mu \mathrm{g})$ antibiotic disc was placed at the center of an agar Mueller-Hinton plate. Around amoxicillin-clavulanic acid disc, the cefotaxime and ceftazidime discs were placed at a distance of 3.0 centimeter $(\mathrm{cm})$ to the center. Development of the zone of inhibition (in a form of "champagne stopper") towards the clavulanic acid disc following incubation at $37{ }^{\circ} \mathrm{C}$ for 24 hours was indicative of a potential ESBL positive Enterobacteriaceae.

\section{Statistical analysis}

Extracted data were entered in Microsoft Excel 2013 spreadsheet and the variables calculated were presented as a percentage. The statistical analysis of all data was done using the STATVIEW Statistical Package version 5 (SAS University Edition, SAS Institute Inc., Cary, USA). The antibiotic susceptibility and rate of carriage of ESBLproducing Enterobacteriaceae were reported as the number of infections per 100 positive patients. In univariate analysis, parameters such as gender, locality, parents level of education, breeding by parents, use of antibiotics in breeding, farming practice by parents, and use of pesticides in agriculture were considered and those with a $\mathrm{p}<0.20$ were selected for further analysis in a multivariate model. Multivariate analyses of characteristic features for the carriage of ESBL-producing Enterobacteriaceae included the following variables; breeding by parents, use of antibiotics in breeding, farming practice by parents, and use of pesticides in agriculture. It was performed using a conditional logistic regression model (SAS University Edition, SAS Institute Inc., Cary, USA) by including the variables suggested by the univariate analysis $(p<0.2)$. All tests were bilateral and 
$\mathrm{p}<0.05$ was considered to be statistically significant.

\section{Administrative and Ethical considerations}

Permission to undertake this study at both remote villages was granted by the regional delegations of the ministries of public health (Reference $\mathrm{N}^{\circ}$ : 185/AR/MINSANTE/DRSPO/DS Bgté) and basic education (Reference $\mathrm{N}^{\circ}$ : N²2/16/L/MINEDUB/DRO/NDE/IAEB-

BGTE/BAG). Besides, ethical approval for the current study was given by the "Université des Montagnes" Ethical Committee (Authorization

N²017/087/UdM/PR/CAB/CIE). Written informed consent was obtained from the parents or guardians on behalf of all the children enrolled in the study.

\section{RESULTS}

\section{Demographic characteristics of school children}

Out of 110 school children enrolled, $36.36 \%$ (40 children) were from "école publique projet route du Noun $2 *$ in the Nde subdivision and $63.63 \%$ (70 children) were from "Moineaux de Bafou Ballefer and Oiselets de Nzi" schools in the Menoua subdivision. The children's age varied from 2 to5 years old and $41 \%$ (45 children) were male and 59\% (65 children) were female. Also, all parents reported that their children have never been hospitalized and have not taken antibiotics during the last 3 months before the study.

\section{Bacteria isolation and identification}

Screening of the fecal flora of 110 school children resulted in 31 positive culture indicating the presence of at least one bacteria strain. Among these cultures, 17 (15\%) of the fecal sample were collected in the Menoua subdivision (Moineaux de Bafou Ballefer and oiselets de Nzi) and 14 (13\%) collected in the Nde subdivision (école publique projet route du Noun 2). In total, bacteria susceptibility to cefotaxime allowed the isolation of 36 strains among which, 23 (64\%) were E. coli. Moreover, the other bacteria strains identified were K. Pneumonia (9\%), E. sakazaki (6\%), S. liquefaciens (6\%), Kluyvera spp (6\%), E. agglomerans (6\%) and the least represented $E$. intermedium (3\%) (Table 1). Further analysis showed that some patients were colonized by more than one micro-organism.

\section{Antimicrobial susceptibility and carriage of extended spectrum beta lactamase-(ESBL)- producing Enterobacteriaceae}

To confirm the presence of the ESBLproducing Enterobacteriaceae, the disc diffusion test was performed using 14 different antibiotic discs. The results showed that $24(22 \%)$ children out of 110 were carrier of ESBL-producing Enterobacteriaceae. A detailed analysis showed that all bacteria isolated from feces were susceptible to ertapenem and resistant to amoxicillin. Also, these bacteria showed a high level of resistance to ciprofloxacin $(90 \%)$ and ofloxacin $(81 \%)$. Moreover, resistance to kanamycin (43\%), amikacin (42\%), and gentamicin $(45 \%)$ was also observed (Table 2). After analysis of the antimicrobial susceptibility tests, 24 of $36(67 \%)$ of the isolated Enterobacteriaceae were ESBLproducing. Also, 17 of the $24(47 \%)$ bacteria isolate were collected in the Ménoua subdivision and 7 of the $24(20 \%)$ were collected in the NDE subdivision. Further analysis indicated that Escherichia coli were the most abundant Enterobacteriaceae isolated with the ESBL phenotype (61\%). Other ESBL-producing bacteria species were Klebsiella pneumoniae (3\%) and Kluyvera spp (Table 3).

Further analysis of antibiotic susceptibility tests showed that some of the isolated Enterobacteriaceae were weakly resistant to the high-level cephalosporins (HLC) $(33 \%)$. In contrast, all of the isolated Enterobacteriaceae showed no resistance to carbapenems $(0 \%)$. The other microorganism which showed resistance to both HLC and EBSL was Kluyvera spp. Distribution of resistance phenotypes displayed by enterobacterial isolates is shown in Table 3.

Risk factors associated with the carriage of the ESBLs-producing Enterobacteriaceae among investigated children

To determine the risk factors associated with the carriage of the ESBLs- 
producing Enterobacteriaceae among children in remote villages, parameters such as sex, locality, parent's educational level, breeding by parents, use of antibiotics on farms, farming practice, and the use of pesticides in agriculture were considered. In the univariate analysis, parameters such as gender, locality, and parent's educational level were not potentially associated with the carriage ESBLs-producing Enterobacteriaceae (Table 4). Therefore, a multivariate analysis was performed for the carrying of the ESBLsproducing Enterobacteriaceae strains, considering the associated variables in univariate analysis with a $p<0.2$ (breeding by parents, the use of antibiotics in breeding, farming practice by parents, and the use of pesticides in agriculture). Neither the history of breeding by parents nor antibiotics usage in breeding appeared to favor the carrying of ESBL strains. In contrast, farming practice by parents (OR 0.17; IC95\%:[0.03-0.99]; $p=0,048)$ and the use of pesticides in agriculture (OR 7.02; IC95\%:[1.47-33,42]; $p=0,014)$ showed a significant association with the carrying of ESBLs-producing Enterobacteriaceae strains (Table 5).

Table 1: Distribution of Enterobacteriaceae strains isolated from school children's stools.

\begin{tabular}{lll}
\hline Bacteria strains & $\begin{array}{l}\text { Size } \\
(\mathbf{n = 3 6 )}\end{array}$ & Percentage \\
\hline Escherichia coli & 23 & 64 \\
\hline Klebsiella pneumoniae & 4 & 9 \\
\hline Enterobacter sakazaki & 2 & 6 \\
\hline Serratia liquefaciens & 2 & 6 \\
\hline Kluyvera spp & 2 & 6 \\
\hline Enterobacter Aglomerans & 2 & 6 \\
\hline Enterobacter intermedium & 1 & 3 \\
\hline
\end{tabular}

Table 2: Antibiotic susceptibility rates of Enterobacteriaceae isolated from healthy school children feces.

\begin{tabular}{llll}
\hline \multirow{2}{*}{ Antibiotics } & \multicolumn{2}{l}{ Phenotypes (percentage) } & \\
\cline { 2 - 4 } Amoxicillin & Sensitive & Intermediate & Resistant \\
\hline Amoxicillin/clavulanic acid & 0 & 0 & 100 \\
\hline Cefoxitin & 0 & 80 & 20 \\
\hline Cefotaxime & 67 & 0 & 33 \\
\hline Ceftazidime & 0 & 0 & 100 \\
\hline Ertapenem & 0 & 20 & 80 \\
\hline Gentamicin & 100 & 0 & 0 \\
\hline Kanamycine & 44 & 11 & 45 \\
\hline Amikacin & 24 & 33 & 43 \\
\hline Ciprofloxacin & 24 & 33 & 43 \\
\hline Triméthoprime/sulfamethoxazole & 10 & 0 & 90 \\
\hline Ofloxacin & 23 & 5 & 81 \\
\hline Nalidixicacid & 13 & 8 & 38 \\
\hline Fosfomycin & 31 & 31 & 40 \\
\hline
\end{tabular}


Table 3: Distribution of resistance phenotypes by Enterobacterial isolates resistant to different antibiotic classes.

\begin{tabular}{llll}
\hline Bacterial strains & \multicolumn{2}{l}{ Phenotype (\%) } \\
\cline { 2 - 4 } & & ESBL $^{\mathbf{b}}$ & \\
\hline & & Carbapenems $^{\mathbf{a}}$ & \\
\hline Klebsiella pneumoniae & 9 & 61 & 0 \\
\hline Escherichia coli & 3 & 0 & 0 \\
\hline Enterobacter sakazaki & 5 & 0 & 0 \\
\hline Serratia liquefaciens & 5 & 3 & 0 \\
\hline Kluyveraspp & 3 & 0 & 0 \\
\hline Enterobacter agglomenrans & 5 & 0 & 0 \\
\hline Enterobacter intermedium & 3 & $\mathbf{6 7}$ & 0 \\
\hline TOTAL & $\mathbf{3 3}$ & $\mathbf{0}$ \\
\hline
\end{tabular}

${ }^{\mathrm{a}}$ High-level cephalosporins; ${ }^{\mathrm{b}}$ Extended-Spectrum Beta-Lactamases.

Table 4: Univariate analysis for parameters associated with the carriage of ESBL-producing bacteria.

\begin{tabular}{|c|c|c|c|}
\hline \multicolumn{4}{|l|}{ Univariate analsis } \\
\hline Variables & *OR & $* * 95 \% \mathrm{CI}$ & $* * * p$-value \\
\hline \multicolumn{4}{|l|}{ Gender } \\
\hline Female & 1 & & \\
\hline Male & 1,29 & {$[0,52-3,22]$} & 0,5795 \\
\hline \multicolumn{4}{|l|}{ Locality } \\
\hline Bafou & 1 & & \\
\hline Bangangté & 0,8 & {$[0,31-2,08]$} & 0,6521 \\
\hline \multicolumn{4}{|c|}{ Parents' education level } \\
\hline Primary schooling & 1 & & \\
\hline High school & 1,18 & {$[0,46-3,02]$} & 0,7308 \\
\hline \multicolumn{4}{|c|}{ Breeding by parents } \\
\hline No & 1 & & \\
\hline Yes & 3,14 & {$[1,14-8,68]$} & 0,0272 \\
\hline \multicolumn{4}{|c|}{ Use of antibiotics in breeding } \\
\hline No & 1 & & \\
\hline Yes & 3,85 & {$[1,49-9,91]$} & 0,0053 \\
\hline \multicolumn{4}{|c|}{ Farming practice by parents } \\
\hline No & 1 & & \\
\hline Yes & 0,14 & {$[0,03-0,63]$} & 0,0103 \\
\hline \multicolumn{4}{|c|}{ Use of pesticides in agriculture } \\
\hline No & 1 & & \\
\hline Yes & 9,13 & {$[2,02-41,26]$} & 0,0041 \\
\hline
\end{tabular}


Table 5: Risk factors associated with the carrying of ESBL-producing enterobacteriaceae in multivariate analysis.

\begin{tabular}{|c|c|c|c|}
\hline $\begin{array}{l}\text { Multivariat } \\
\text { Parameters }\end{array}$ & $* \mathbf{O R}$ & $* * \mathrm{CI} 95 \%$ & $p$-value $* * *$ \\
\hline \multicolumn{4}{|c|}{ Use of pesticides in agriculture } \\
\hline No & 1 & & \\
\hline Yes & 7,02 & {$[1,47-33,42]$} & 0,0144 \\
\hline \multicolumn{4}{|c|}{ Use of antibiotics in breeding } \\
\hline No & 1 & & \\
\hline Yes & 3,19 & {$[0,75-13,50]$} & 0,1154 \\
\hline \multicolumn{4}{|c|}{ Farming practice by parents } \\
\hline No & 1 & & \\
\hline Yes & 0,17 & {$[0,03-0,99]$} & 0,0481 \\
\hline \multicolumn{4}{|c|}{ Breeding by parents } \\
\hline No & 1 & & \\
\hline Yes & 1,06 & {$[0,21-5,33]$} & 0,9420 \\
\hline
\end{tabular}

\section{DISCUSSION}

The current study was undertaken to determine the prevalence of community-based extended-spectrum beta lactamase-(ESBL)producing Enterobacteriaceae in healthy school children of 02-05 years old in two remote villages of west Cameroon. The main features of the investigated children that they have never been hospitalized and had not been treated with antibiotics 3 months before the study. The main finding is a high carriage rate of ESBL- producing Enterobacteriaceae by children in a region where no healthcare structure is present and the use of antibiotics is not common. Comparatively, the prevalence obtained in this study far lower than the one reported by Farra et al. (2016) among children in Bangui. Besides, weak resistance to highlevel cephalosporins and no resistance to carbapenems were observed. Furthermore, regression analyses showed that farming practices by parents who use pesticides in crops was associated with carriage of ESBLproducing Enterobacteriaceae by children, who were exposed to pesticide through consumption of agricultural products. This view point is supported by articles claiming that people exposed to pesticides develop resistance to antibiotics (Curutiu et al., 2017;
Malagón-Rojas et al., 2020). This is the first study in Cameroonian rural community reporting on ESBL carriage among healthy children. Fecal carriage of ESBL-producing Enterobacteriaceae has been documented in both children and adults (Isendahl et al., 2012; Stoesser et al., 2015; Desta et al., 2016; Karanika et al., 2016; Kommedal et al., 2016; Mshana et al., 2016; Reuland et al., 2016). The global prevalence of $14 \%$ ESBL carriage among healthy individuals has been reported (Karanika et al., 2016) and in sub-Sahara Africa, few studies have investigated the prevalence of ESBL-carriage among children (Schaumburg et al., 2013; Farra et al., 2016; Mshana et al., 2016).

This work reveals the presence of a significant reservoir of ESBLEnterobacteriaceae in the community. The results obtained show an overall prevalence of ESBL-Enterobacteriaceae colonization of $67 \%$ among healthy children in the studied communities. This prevalence is very high compared to $16 \%$ reported by Lonchel et al. (2012) in Ngaoundere, Cameroon and, 4.6\% carriage among healthy French children (Birgy et al., 2012). The lower prevalence obtained among healthy French children may be explained by the difference in hygienic 
conditions between France and Cameroon. In contrast, the prevalence obtained in this study is lower than the one obtained in Chad (38\%) in community children (Ouchar-Mahamat et al., 2019). The current data indicating a higher prevalence of ESBL-Enterobacteriaceae (22\%) in the community children is surprising and was not expected given the fact that the areas investigated have no hospital and inhabitants are not used to antibiotic consumption. One of the possible explanations of the appearance of the ESBL phenotype in such a region is that the phenotype may arise from pesticides use used by farmers in crops and these may contaminate foods consumed by inhabitants of the village. Indeed, I has been demonstrated that exposure of bacteria to herbicides induce the expression of certain genes that they all carry, but don't always use (Kurenbach et al., 2015; Curutiu et al., 2017; Ramakrishnan et al., 2019; Zhang et al., 2019; Malagón-Rojas et al., 2020). These genes are part of the socalled "adaptive response" and the main elements of this response are proteins that "pump" toxins out of the cell, keeping intracellular level concentration sub-lethal (Kurenbach et al., 2015; 2017; 2018).

Further data analysis found carriage of more than one bacteria species common among children in the community investigated, increasing the risk of transfer of genetic materials responsible for the resistance to other bacteria. This idea is supported by finding suggesting that carriage of more than one bacteria species might increase the risk of transfer of genetic elements causing resistance (García-Rodríguez et al., 2002). In this study, we did not carry out extensive molecular characterization to determine the genotype of each isolate. However, it is demonstrated that the CTX-M-15 like genotype is the dominant CTX-Ms enzyme among carriers worldwide (Karanika et al., 2016). Therefore the CTXM-15-like genotype might be the one present in ESBL-positive isolates recorded in our community. Besides, SHV-type ESBL might also be considered as one of the possible genotypes of ESBL-positive isolates.

The main ESBL-producing Enterobacteriaceae strains isolated in this study was E. coli which is the frequently reported Enterobacteriaceae in hospital-based (Blomberg et al., 2005; Zaidi et al., 2005; 2009) and community-based (Huynh et al., 2015; Islam et al., 2018) studies in other African countries. Although the current study found a significantly higher prevalence of ESBL-producing Enterobacteriaceae among healthy community children in a remote region of western Cameroon, the clinical impact of multidrug-resistant bacteremias has yet to be investigated. This study seems to be the only one conducted in Cameroon which has targeted children in remote villages where the use of antibiotics is rare. Besides, the clinical consequences of ESBL bacteremia in such remote regions have to be evaluated and the significant impact of these multi-resistant infections on mortality of children in that region has to be shown. These results should encourage health authorities to investigate whether multidrug-resistant bacteremia is among the causes of death in children aged 0 5 years recorded in remote villages or rural Cameroon.

\section{Conclusion}

This study showed the presence of Enterobacteriaceae having a high level of antibiotic resistance among the subjects who had in all probability antibiotics naive. It therefore confirms that environmental conditions have a high roll in the transmission of Enterobacteriaceae resistance. Therefore, we believe on the one hand that the farmers must avoid anarchic use of pesticides and herbicides for plant treatment, and on the other hand that all peoples in such an area must apply the strict rule of hygiene to avoid infection.

\section{COMPETING INTERESTS}

The authors declare that they have no competing interests. 


\section{AUTHORS' CONTRIBUTIONS}

The conception and design of this study were made by SNF. Patient recruitment, sample, and data collection were done by LWNN, ITL, and ACB. The study was coordinated by SNF. Data analysis and interpretation were performed by $\mathrm{SNF}$ and LWNN. SNF wrote the manuscript. All authors read and approved the final manuscript.

\section{ACKNOWLEDGMENTS}

The authors would like to thank the members of the laboratory of the microbiology of the "Clinique Universitaire des Montagnes" who contributed to this study. We would also like to thank Dr. Djuikwo Félicité for critical reading.

\section{REFERENCES}

Aminov RI. 2010. A brief history of the antibiotic era: lessons learned and challenges for the future. Front. Microbiol., 1: 134. DOI: https://doi.org/10.3389/fmicb.2010.0013 4

Arpin C, Quentin C, Grobost F, Cambau E, Robert J, Dubois V, Coulange L, Andre C. on behalf of the Scientific Committee of ONERBA. 2009. Nationwide survey of extended-spectrum b-lactamaseproducing Enterobacteriaceae in the French community setting. $J$. Antimicrob. Chemother., 63:1205-14. DOI: https://doi.org/10.1093/jac/dkp108

Bebell LM, Muiruc AN. 2014. Antibiotic use and emerging resistance-how can resource-limited countries turn the tide? Glob Heart., 9(3): 347-358. DOI: https://doi:10.1016/j.gheart.2014.08.009

Ben-Ami R, Schwaber MJ, Navon-Venezia S, Schwartz D, Giladi M, Chmelnitsky I, Leavitt A, Carmeli Y. 2006. Influx of extended-spectrum beta-lactamaseproducing Enterobacteriacea into the hospital. Clin. Infect. Dis., 42: 925-934. DOI: https://doi.org/10.1086/500936
Birgy A, Cohen R, Levy C, Bidet P, Courroux C, Benani M, Thollot F, Bingen E. 2012. Community faecal carriage of extendedspectrum beta-lactamase-producingEnterobacteriaceae in french children. BMC Infect. Dis., 12: 315. DOI: http://doi.org/10.1186/1471-2334-12-315 Blomberg B, Jureen R, Manji KP, Tamim BS, Mwakagile DS, Urassa WK, Fataki M, Msangi V, Tellevik MG, Maselle SY, Langeland N. 2005. High Rate of Fatal Cases of Pediatric Septicemia Caused by Gram-Negative Bacteria with ExtendedSpectrum Beta-Lactamases in Dar es Salaam, Tanzania. J. Clin. Microbiol., 43: 745-49. DOI: http://doi.org/10.1128/JCM.43.2.745749.2005

Boucher HW, Talbot GH, Bradley JS, Edwards JE, Gilbert D, Rice LB, Boucher HW, Talbot GH, Bradley JS, Edwards JE, Gilbert D, Rice LB. 2009. Bad bugs, no drugs: no ESKAPE! An update from the Infectious Diseases Society of America. Clin. Infect. Dis., 48: $1-12$. DOI: https://doi.org/10.1086/595011

Brown C, Alhassan A-N. 2014. Multipleantibiotic-resistant bacteria from cockroaches trapped from a public hospital and a nearby students' hostel in Accra, Ghana. Int. J. Biol. Chem. Sci., 8(4): $\quad$ 1859-1864. DOI: http://dx.doi.org/10.4314/ijbcs.v8i4.44

Bryce A, Costelloe C, Hawcroft C, Wootton M, Hay DA. 2016. Faecal carriage of antibiotic resistant Escherichia coli in asymptomatic children and associations with primary care antibiotic prescribing: a systematic review and meta-analysis. BMC Infect. Dis., 16: 359 . DOI: http://doi.org/10.1186/s12879-016-16976

Carlet J. 2012. The gut is the epicentre of antibiotic resistance. Antimicrob. Resist. Infect. Control, 1: 39. DOI: http://doi.org/10.1186/2047-2994-1-39 
Comité de l'antibiogramme de la société française de microbiologie (CA-SFM). 2015. 1-117. https://www.sfmmicrobiologie.org/wp content/uploads/2018/12/CASFMV2_SE PTEMBRE2018.pdf

Curutiu C, Mariana VL, Chifiriuc C. 2017. Pesticides and antimicrobial resistance: from environmental compartments to animal and human infections. In New Pesticides and Soil Sensors, Grumezescu AM (ed.). Academic press; 373-392.

De Champs C, Sauvant MP, Chanal C, Sirot D, Gazuy N, Malhuret R, Baguet JC, Sirot J. 1989. Prospective survey of colonization and infection caused by expanded-spectrum-betalactamaseproducing members of the family Enterobacteriaceae in an intensive care unit. J. Clin. Microbiol., 27(12): 288790.

Desta K, Woldeamanuel Y, Azazh A, Mohammod H, Desalegn D, Shimelis D, Gulilat D, Lamisso B, Makonnen E, Worku A, Mannerqvist K, Struwe J, Aspevall O, Aklillu E. 2016. High Gastrointestinal Colonization Rate with Extended-Spectrum beta-LactamaseProducing Enterobacteriaceae in Hospitalized Patients: Emergence of Carbapenemase-Producing $K$. pneumoniae in Ethiopia. PLoS One, 11: $\mathrm{e} 0161685$.

DOI:

https://doi.org/10.1371/journal.pone.016 1685

Donskey CJ. 2004. The role of the intestinal tract as a reservoir and source for transmission of nosocomial pathogens. Clin. Infect. Dis., 39: 219-226. DOI: https://doi.org/10.1086/422002

Duval-Iflah Y, Raibaud P, Tancrede C, Rousseau M. 1980. R-plasmic transfer from Serratia liquefaciens to Escherichia coli in vitro and in vivo in the digestive tract of gnotobiotic mice associated with human fecal flora. Infect. Iтmип., 28: 981-990.
Farra A, Frank T, Tondeur L, Bata P, Gody JC, Onambele M, Rafaï C, Vray M, Breurec S. 2016. High rate of faecal carriage of extended-spectrum blactamase-producing Enterobacteriaceae in healthy children in Bangui, Central African Republic. Clin. Microbiol. Infect., 22(10): 891. DOI: http://doi.org/10.1016/j.cmi.2016.07.001

García-Rodríguez JA, Martínez MJF. 2002. Dynamics of nasopharyngeal colonization by potential respiratory pathogens. J. Antimicrobial. Chemotherapy, 50(Suppl. S2): 59-73. DOI: http://doi.org/10.1093/jac/dkf506

Huynh B-T, Padget M, Garin B, Herindrainy P, Kermorvant-Duchemin E, Watier L, Guillemot D, Delaroque-Astagneau E. 2015. Burden of bacterial resistance among neonatal infections in low income countries: how convincing is the epidemiological evidence? BMC Infect. Dis., $\quad 15$ : $127 . \quad$ DOI: http://doi.org/10.1186/s12879-015-0843$\mathrm{X}$

Iqbal R, Ikram N, Shoaib M, asad MJ, Mehmood RT, Niazi A, Asghar A, Ishfaq B, Naseer F. 2017. Phenotypic cofirmatory disc diffusion test (PCDDT), double disc synergy test (DDST), E-test OS diagnostic tool for detection of extended spectrum beta lactamase (ESBL) producing Uropathogens. $J$. Appl. Biotechnol. Bioeng., 3(3): 344349.

DOI: http://doi.org/10.15406/jabb.2017.03.000 68

Isendahl $\mathrm{J}$, Turlej-Rogacka A, Manjuba $\mathrm{C}$, Rodrigues A, Giske CG, Naucler P. 2012. Fecal carriage of ESBL-producing E. coli and $K$. pneumoniae in children in Guinea-Bissau: a hospital-based crosssectional study. PLoS One, 7(12): e51981. DOI: http://doi.org/10.1371/journal.pone.0051 981

Islam S, Selvarangan R, Kanwar N, McHenry R, Chappell JD, Halasa N, Wikswo ME, 
Payne DC, Azimi PH, McDonald LC, Gomez-Duarte OG. 2018. Intestinal carriage of third-generation cephalosporin-resistant and extendedspectrum $\quad \beta$-lactamase-producing Enterobacteriaceae in healthy US children. J. Pediatric Infect. Dis. Soc., 7(3): 234-240. DOI: http://doi.org/10.1093/jpids/pix045

Karanika S, Karantanos T, Arvanitis M, Grigoras C, Mylonakis E. 2016. Fecal Colonization With Extendedspectrum Beta-lactamase-Producing

Enterobacteriaceae and Risk Factors Among Healthy Individuals: A Systematic Review and Metaanalysis. Clin. Infect. Dis., 63: 310-18. DOI: http://doi.org/10.1093/cid/ciw283

Kommedal O, Aasen JL, Lindemann PC. 2016. Genetic antimicrobial susceptibility testing in Gram-negative sepsisimpact on time to results in a routine laboratory. APMIS., 124: 603-10. DOI: http://doi.org/10.1111/apm.12549

Kurenbach B, Marjoshi D, Amábile-Cuevas CF, Ferguson GC, Godsoe W, Gibson P, Heinemann JA. 2015. Sublethal exposure to commercial formulations of the herbicides dicamba, 2,4dichlorophenoxyacetic acid, and glyphosate cause changes in antibiotic susceptibility in Escherichia coli and Salmonella enteric serovar Typhimurium. M. Bio., 6(2): e00009-15. DOI:

http://doi.org/10.1128/mBio.00009-15

Kurenbach B, Gibson PS, M Hill AM, Bitzer AS, Silby MW, Godsoe W, Heinemann JA. 2017. Herbicide ingredients change Salmonella enterica sv. Typhimurium and Escherichia coli antibiotic responses. Microbiology, 163(12): 17911801.

DOI: http//doi:10.1099/mic.0.000573.

Kurenbach B, Hill AM, Godsoe W, van Hamelsveld S, Jack A Heinemann JA. 2018. Agrichemicals and antibiotics in combination increase antibiotic resistance evolution. Microbiology, 6: e5801.

DOI: http://doi:10.7717/peerj.5801.

Lonchel CM, Meex C, Gangoué-Piéboji J, Boreux R, Assoumou M-CO, Melin P, De Mol P. 2012. Proportion of extendedspectrum B-lactamase-producing Enterobacteriaceae in community setting in Ngaoundere, Cameroon. BMC Infect. Dis., $\quad$ 12: $53 . \quad$ DOI: http://doi.org/10.1186/1471-2334-12-53

Malagón-Rojas JN, Parra-Barrera EL, Lagos L. 2020. From environment to clinic: the role of pesticides in antimicrobial resistance. Rev. Panam. Salud. Publica., 44: e44. DOI: https://doi.org/10.26633/RPSP.2020.44

Mesa RJ, Blanc V, Blanch AR, Cortés P, González JJ, Lavilla S, Miró E, Muniesa M, Saco M, Tórtola MT, Mirelis B, Coll P, Llagostera M, Prats G, Navarro F. 2006. Extended-spectrum betalactamase-producing Enterobacteriaceae in different environments (humans, food, animal farms and sewage). $J$. Antimicrob. Chemother., 58(1): 211-215. DOI: http://doi.org/10.1093/jac/dkl211

Mshana SE, Falgenhauer L, Mirambo MM, Mushi MF, Moremi N, Julius R, Seni J, Imirzalioglu $\mathrm{C}$, Matee $\mathrm{M}$, Chakraborty Y. 2016. Predictors of blaCTXM-15 in varieties of Escherichia coli genotypes from humans in community settings in Mwanza, Tanzania. BMC Infect. Dis., 16: $187 . \quad$ DOI: http://doi.org/10.1186/s12879-016-1527$\mathrm{x}$

Munita MJ, Arias AC. 2015. Mechanisms of Antibiotic Resistance. Microbiol. Spectr., $\quad$ 4(2): $\quad$ 10.1128. DOI: http://doi.org/10.1128/microbiolspec.V MBF-0016-2015

Ngassam RFT, Tantse M, Kwetche PRF, Noumi DPN, Kouamouo J, Louokdom JS, Dongmo SG, Tchoukoua SH, Kweyang BPT, Kourouma K. 2017. Multicenter study on antibiotic susceptibility/resistance trends in the 
western region of Cameroon. Int. J. Biol. Chem. Sci., 11(1): 131-143. DOI: http://dx.doi.org/10.4314/ijbcs.v11i1.11

Ny S, Löfmark S, Börjesson S, Englund S, Ringman M, Bergström J, Nauclér P, Giske CG, Byfors S. 2017. Community carriage of ESBL-producing 253 Escherichia coli is associated with strains of low pathogenicity: A Swedish 254 Nationwide Study. J. Antimicrob. Chemother., 72(2): 582-588. DOI: https://doi.org/10.1093/jac/dkw419

Ouchar-Mahamat O, Tidjani A, Lounnas M, Hide M, Benavides J, Somasse C, Ouedraogo A-S, Sanou S, Carrière C, Bañuls A-L, Jean-Pierre H, Dumont Y, Godreuil S. 2019. Fecal carriage of extended-spectrum $\quad \beta$-lactamaseproducing Enterobacteriaceae in hospital and community settings in Chad. Antimicrob. Resist. Infect. Control, $\quad 8: \quad 169 . \quad$ DOI: https://doi.org/10.1186/s13756-0190626-z

Piebeng GNK, Tamungang SA, Ngwa CF, Ndukum ja, Bayoï JR, Gapessie L, Katte B. 2014. Profils bactériens et fongiques dans les fèces des tisserins villageois (Ploceus cucullatus) dans la ville de Dschang et ses environs (OuestCameroun). Int. J. Biol. Chem. Sci., 8(4): 1771-1783.

DOI: http://dx.doi.org/10.4314/ijbcs.v8i4.35

Ramakrishnan B, Venkateswarlu K, Sethunathan N, Megharaj M. 2019. Local applications but global implications: Can pesticides drive microorganisms to develop antimicrobial resistance? Sci. Total Environ., 654: 177189.

DOI:

https://doi.org/10.1016/j.scitotenv.2018. 11.041

Reuland EA, Al Naiemi N, Kaiser AM, Heck M, Kluytmans JA, Savelkoul PH, Elders PJ, Vandenbroucke-Grauls CM. 2016. Prevalence and risk factors for carriage of ESBL-producing Enterobacteriaceaein Amsterdam. $J$.
Antimicrob. Chemother., 71(4): 1076-82. DOI: https://doi.org/10.1093/jac/dkv441

Rodríguez-Baño J, Navarro JD, Romero L, Martínez-Martínez L, Muniain MA, Perea EJ, Pérez-Cano R, Pascual A. 2004. Epidemiology and Clinical Features of Infections Caused by Extended-Spectrum Beta-LactamaseProducing Escherichia coli in Nonhospitalized Patients. J. Clin. Microb., 42(3): 1089-94. DOI: http://doi.org/10.1128/JCM.42.3.10891094.2004

Schaumburg F, Alabi A, Kokou C, Grobusch MP, Kock R, Kaba H, Becker K, Adegnika AA, Kremsner PG, Peters G, Mellmann A. 2013. High burden of extended-spectrum beta-lactamaseproducing Enterobacteriaceaein Gabon. J. Antimicrob. Chemother., 68(9): 214043.

DOI: https://doi.org/10.1093/jac/dkt164

Schwaber MJ, Carmeli Y. 2007. Mortality and delay in effective therapy associated with extended-spectrum b-lactamase production in Enterobacteriaceaebacteraemia: a systematic review and meta-analysis. $J$. Antimicrob. Chemother., 60: 913-20. DOI: https://doi.org/10.1093/jac/dkm318

Stoesser N, Xayaheuang S, Vongsouvath M, Phommasone K, Elliott I, Del Ojo Elias C, Crook DW, Newton PN, Buisson Y, Lee SJ, Dance DA. 2015. Colonization with Enterobacteriaceae producing ESBLs in children attending pre-school childcare facilities in the Lao People's Democratic Republic. J. Antimicrob. Chemother., 70(6): 1893-97. DOI: https://doi.org/10.1093/jac/dkv021

Tellevik MG, Blomberg B, Kommedal $\varnothing$, Maselle SY, Langeland N, Moyo SJ. 2016. High prevalence of faecal carriage of ESBL-Producing Enterobacteriaceae among children in Dar es Salaam, Tanzania. PLoS ONE, 11(12): e0168024. DOI:https://doi.org/10.1371/journal.pone .0168024 
Toudji AG, Djeri B, Karou SD, Tigossou S, Ameyapoh Y, de Souza C. 2017. Prévalence des souches d'entérobactéries productrices de bêta-lactamases à spectre élargi isolées au Togo et de leur sensibilité aux antibiotiques. Int. J. Biol. Chem. Sci., 11(3): 1165-1177. DOI: https://dx.doi.org/10.4314/ijbcs.v11i3.19

WHO. 2014. Antimicrobial resistance: Global report on surveillance. WHO, Geneva: World Health Organization.

Woerther PL, Angebault C, Jacquier H, Hugede HC, Janssens AC, Sayadi S, El Mniai A, Armand-Lefèvre L, Ruppé E, Barbier F, Raskine L, Page AL, de Rekeneire N, Andremont A. 2011. Massive increase, spread, and exchange of extended spectrum $\beta$-lactamaseencoding genes among intestinal Enterobacteriaceae in hospitalized children with severe acute malnutrition in Niger. Clin. Infect. Dis., 53: 677-85. DOI: https://doi.org/10.1093/cid/cir522

Woerther PL, Burdet C, Chachaty E, Andremont A. 2013. Trends in human fecal carriage of extended-spectrum beta-lactamases in the community: toward the globalization of CTX-M. Clin. Microbiol. Rev., 26: 744-58. DOI: http:// doi.org/10.1128/CMR.00023-13

Zaidi AKM, Charles-Huskins C, Thaver D, Bhutta ZA, Abbas Z. Goldmann DA. 2005. Hospital-acquired neonatal infections in developing countries. Lancet, 365: 1175-88. DOI: https://doi.org/10.1016/S01406736(05)71881-X

Zaidi AKM, Thaver D, Ali SA, Kan TA. 2009. Pathogens associated with sepsis in newborns and Young children in developing countries. Pediatric Infect. Dis., $\quad 28$ : 10-18. DOI: http://doi.org/10.1097/INF.0b013e31819 58769

Zhang Q, Zhu D, Ding J, Zheng F, Zhou S, Lu T, Zhu YG, Qian H. 2019. The fungicide azoxystrobin perturbs the gut microbiota community and enriches antibiotic resistance genes in Enchytraeus crypticus. Env. Int., 131: 104965. DOI: https://doi.org/10.1016/j.envint.2019.104 965. 